\title{
The Impacts of Information Communication Technology (ICT) on the Teaching and Learning of English as a Second Language in Nigerian Secondary Schools
}

Akinbode, Joseph Oluwole (PhD)

\begin{abstract}
The roles of Information Communication Technology (ICT) in the trend of English Language teaching and learning are enormous. These include globalisation of the teaching and learning of English Language, the use of technology to make teaching and learning of English as a Second Language communicative and functional and the development of the trendy English Language teacher. This study in consonance with the foregoing is aimed at examining the impacts of Information Communication Technology (ICT) on the teaching and learning of English as a Second Language in Nigerian secondary schools.
\end{abstract}

\section{Introduction}

Teaching and learning opportunities can be expanded through appropriate application of technology (Aborisade 2005). By 1997 following the communication skills project workshops held in Nigeria and the United Kingdom, a form of team teaching was being practised at the University of Agriculture, Abeokuta (Alani et al, 1997). About the same period, and following the same teacher development opportunity, the Federal University of Technology, Akure had overhauled its curriculum and adapted a new skills and taskbased syllabus; this was based on a Needs Analysis carried out (Aborisade, 1997). In virtually every institution of higher 
learning which had participated in the teacher development programme jointly organised by the NUC and British Council on behalf of the Overseas Development Administration (ODA), new teaching ideas were being tried out. That initiative had ended without a thought for how the impetus set in motion could be sustained.

As the trendy teachers of a language, fresh thinking, new ways, novel methods, new media of presenting our lessons for the benefit of our learners are required. To achieve these laudable objectives, two possibilities are available to us. One, self development as a group: to exchange ideas and classroom practices, together to develop new methodologies which are appropriate for our situation, to develop materials which address the language problems of our learners. Two, to learn to apply the new technologies in the process of the self development, both for professional development and the integration of teaching materials and methodology of presentation and take advantage of materials available widely around us. This is where technology and globalisation become relevant (Aborisade 2005).

\section{Technology and Literacy}

The Phoenicians invented the syllabary around 1100BC. The basis for Western literacy was the invention of alphabetic writing by the Greeks (Murray, 2000). It is the subject of conjecture that led Phoenicians to their invention, but accounts indicated that theirs was a mercantile culture and as such the impetus might have been need for record keeping. In the $15^{\text {th }}$ century, (1450) the printing press was introduced. This new technology, Einstein (1979) claims mechanizes human memory, made food for thought more abundant and allowed cognitive energy to be used more 
efficiently. Two things distinguish writing from printing: They are: prints capacity to duplicate texts in large numbers and to preserve texts and images over long period of time.

In Europe, the technology of literacy remained in the hands of the elite (priests, monarchy) for a long time, because of the cost of printed books. Printing technology was also made possible because of development in the area of metallurgy. (Aborisade, 1997). Print took time to affect lives of the ordinary people. According to Cook (1990) only about 200 copies of the Gutenberg Bible were ever produced fifty years after Gutenberg only about $10 \%$ of the people could read. It took the mass literacy campaigns of the Protestant Reformers before "significant population of readers that could take advantage of the pictures and texts which the printing press made available to them (Tyner, 1998). Even so, it was not until the end of the $18^{\text {th }}$ century that illiteracy began to decline to near $50 \%$, mostly as a result of the need for reading and writing at work, especially in trades which needed to keep records (Aborisade, 1997). And the decline in illiteracy was itself due more to the changes in social consciousness brought about, in part, by effects of industrialization process; individualism, nationalism and heightened secularism.

\section{Technology and Language Education}

Computer and Internet have of recent been a means of communication and education for instance; today English Language is the language of the Internet and language of science and technology. Murray (2000), with regard to literacy technology and language education observed that:

Computer technology has facilitated trends already present in pedagogical theory - 
collaboration (or cooperative learning) as a means of learning, a view of writing as social, reader response theory, and the teacher as mentor-coach rather than purveyor of received knowledge (Murray, 2000).

Developments in linguistic research bring with them new approaches which affect methodologies and pedagogical practice (Rodgers 2000, Odejide, 2003). In relation to technology, this position is corroborated by Kuang-wu 2000) who maintains "the first form of computer assisted language learning featured repetitive language drills, referred to as drill and practice method. It was based on the behaviourist learning model".

Table 1: Teaching Methods and Teacher and Learner Roles

\begin{tabular}{|l|l|l|}
\hline Method & Teacher Roles & Learner Roles \\
\hline Situational language & Content setter & Initiator \\
\hline Teaching & Error corrector & Memorizer \\
\hline Audio-lingualism & $\begin{array}{l}\text { Language Modeler } \\
\text { Drill leader }\end{array}$ & $\begin{array}{l}\text { Pattern practiser } \\
\text { Accuracy } \\
\text { Enthusiast }\end{array}$ \\
\hline Communicative & Needs Analyst & Improvisor \\
\hline Language Teaching & Task Designer & Negotiator \\
\hline $\begin{array}{l}\text { Total physical } \\
\text { response }\end{array}$ & $\begin{array}{l}\text { Commander } \\
\text { Action Monitor }\end{array}$ & $\begin{array}{l}\text { Order Taker } \\
\text { Performer }\end{array}$ \\
\hline $\begin{array}{l}\text { Community } \\
\text { language } \\
\text { Learning }\end{array}$ & $\begin{array}{l}\text { Counsellor } \\
\text { Paraphraser }\end{array}$ & $\begin{array}{l}\text { Collaborator } \\
\text { Whole person }\end{array}$ \\
\hline $\begin{array}{l}\text { The } \\
\text { approach natural }\end{array}$ & $\begin{array}{l}\text { Action } \\
\text { Prop user }\end{array}$ & $\begin{array}{l}\text { Guesser } \\
\text { Immerser }\end{array}$ \\
\hline Suggestopedia & $\begin{array}{l}\text { Auto Hypnotist } \\
\text { Authority figure }\end{array}$ & $\begin{array}{l}\text { Relaxer } \\
\text { True Believer }\end{array}$ \\
\hline
\end{tabular}

Source: Odejide (2003) "What methodologies"...? 
Odejide concludes that... "specific language activities presupposes an underlying method and perception of teacher and students roles". Rogers in reiterating an earlier position contends that:

The $20^{\text {th }}$ century has seen an immense amount of activity in language teaching methodology. Grammar translation, Direct method, Audio-lingualism - all preceded what some have called the age of methods, comprising most of the last decades of this century (Rogers, 2000).

Rogers concludes that any successful educational design "comprises four kinds of considerations, which we have called knowledge, instructional, learner and administrative considerations. This last includes "methods, materials, programmes, technologies and educational environments. The issue today, therefore, is how teachers can integrate their guiding linguistic theories, teaching methods, teacher and student roles with new knowledge technologies. The question of teacher competencies then arises! Are language teachers sufficiently competent to adapt and use new technologies for their purposes? Are the technologies readily available for use? What kind of teaching and learning environments do the teachers have to accommodate these technologies? Can Nigerian language teachers compete under the dominant dual ideology of neoliberalism and techno-materialism? (Aborisade 1997). 


\section{The Internet and English as a Second Language (ESL): Resources and Roles}

The expression Information and Communication

Technology refers to series of technology which include the computer. The information and communication technology materials are characterised by their power to memorise process or make accessible (on screen) and to transit in principle to any at all, a virtually unlimited and extremely diversified quantity of data. These new technologies are found with increasing frequency in various forms, text, diagram, graphs, moving images, sound etc. It is not possible to take stock of their contributions in the same way as one would an existing education technology.

In essence, the contributions of those materials traditionally referred to as 'instructional aids' as existing educational technology have become common place and subject of many successful research works. The perspective taken by educational researchers and practitioners concerning roles of computer-based learning technologies in the classroom has shifted significantly in the past decade. The perspective of the early 1980s can be characterized as "the computer as an agent of change". According to Gergel (1986) the technology was expected to have a major and direct impact on students' learning and skills acquisition. This was particularly the case for the subject areas of writing (where word processing, software was immediately available) and of Mathematics (where various computer-based logo, software was widely available (Gergel 1986).

In the field of English, Herwisher (1991) claimed that there were two broad areas of technological focus a decade ago: the use of computers in writing instruction and the 
incorporation of technology into concepts and definitions of literacy.

Glister (1997) and others addressed the evolution of new conceptions of literacy as a result of the proliferation of computer technology. Today "expand our cognition and the current technology industry" provides a perpetual stream of new tools daily. In turn, these tools create the need for new skills, flexibility and a critical eye. Technology, especially in the form of hypertext, which fosters connections on the internet, has become an essential medium for this emerging literacy, due to its growing prevalence and importance in our society and our interaction with the rest of the world as Myers asserted:

One looks smart in the contemporary world by having a distributed network of tools that helps in solving problem what some have called distributed intelligent the creation of one's own customized, distributed system is one of the first requirement of a thinking person in this post modern age so that we are never without necessary tools if we need them.

Glister (1997) place the emphasis more specifically on digital literacy or the ability to access networked computer resources and use them to understand manipulative information in multiple formats from a wide range of source. Glister (1997) examined the effect of hypermedia on grammar instruction and learning. She developed a hypermedia courseware though authoring tools such as micromedia, autoware and director. Post treatment scores showed that participants achievement, significantly increased, 
confirming the premises that hypermedia based instruction is very effective for grammar teaching and learning.

However, the proficiency level and instructional section did not have significant effects on learning time. The performance of learners with different cognitive styles did not significantly differ indicating that hypermedia-based instruction could accommodate the needs and ability of different individuals.

Moreover, the computer laboratory enhances the students' performance in English Language. Computer laboratory is very useful in the teaching of vocabulary grammar and listening comprehension. Computer laboratory also improves the students listening skills and the students enjoy having regularly scheduled laboratory sessions. They prefer to learn vocabulary and grammar in the classroom and feel that having an instructor present in the computer laboratory increase their learning potentials (Lawton 1975).

Use of technology in language instruction also has varying effects on students' attitudes towards foreign or second language instruction. Furthermore, students are positively inclined to working with web and find it useful, with the majority preferring to use the web as a supplement to face-to-face teaching. They also enjoy using the programme and feel it helps them learn and they enjoy having teacher supervision while using the programme individually (Lawton 1975)

\section{The Impact of Information Technology on Second Language Learning}

It works to validate individual students and empowers their ability to achieve and 'real world' success. It supplements and enhances instruction and, in effect, works almost trans seamlessly with context instruction. It also 
supplements and enhances traditional print / literature/media materials and provides additional resources and creates wider access to them. It expands students' means of expression and deepens their understanding of complex issues and enhances their global connections. It expands and enhances the definitions and dimension of literacy (critical media and otherwise). It also facilitates an open forum for discussion which allows for more opportunities and democratic participation and dialogue.

\section{What Technology Should Not Do}

Technology should not replace complex language and developmental goals with "simpler technology" goals. It should not replace teachers or pedagogy. It should not also complicate or supersede content instruction or become the content for instruction itself. It should not replace or overshadow traditional print/literature / media materials. It should not limit appropriate resources on access to them. It should not also disrupt or complicate normal classroom community efforts and it should not deepen social, racial, gender and economic inequalities. It should not stifle creativity or opportunities for using the imagination. It should completely replace teacher to student and or student to student "face to face communication and interaction.

\section{English Language Information Communication Technology (ICT) Teaching Materials}

A CD-ROM is a very useful instructional material in English Language teaching and learning. A good starting point for a CD-ROM collection for English Language teaching would be Longman Interactive Dictionary (LIED), a collection of linked reference works including dictionary, a dictionary of common errors, a grammar, plus a connection of pictures and even a small library of video clips illustrating language 
functions. Also to be used are English discoveries, which take teenage beginners to upper-intermediate level and Longman's Desktop English. Others are based on existing textbooks, English, Works, for example, identical in terms of content (including illustrations) to the Robert O'Neil book of the same title. 'Flying colours' draws all its materials from Simon Grenalls "Reward". The approach adopted by each is very important. English works offer a strictly limited amount of "added value" listen and repeat, take the part of one of speakers in a dialogue and multi-lingual help, whereas 'flying colours' extends the book-based material with video clips and an unusually wide variety of computer-based exercises. Other materials (basic skills and connections, for example or telephone talk and small talk) are little more than attractively packaged phrase books with unimaginative exercise types and no use of video.

\section{Multimedia in Use}

CD-ROM is not the ideal platform for multimedia language learning materials; it seems likely that the current CD-ROM standard will be replaced within the next five years by a new, "super-density" disk. And increasingly, multimedia materials will be delivered not on a physical but on the Internet. It is important to distinguish multimedia materials from the medium on which they are delivered. There is nothing special about the silver $\mathrm{CD}$. It is merely a convenient way of storing large amounts of information. The exercises, the graphics and the sound clips could all be stored on floppy disks, the fact that a CD-ROM has the capacity of some copy (400) floppies just makes it handier to use.

CD-ROM first became popular because of their ability to store large quantities of text, video, however, is much more demand of storage space than simple text. Typically, a 
CD-ROM can hold only ten to twenty minutes of video, and even clips are usually delivered in a small window covering only a quarter of the screen, with poor picture definition, jerky movements and a total absence of lip-synchronization.

\section{The Internet}

As the Internet has transformed communication around the world, it is natural that it should play a major role in the foreign language classroom. If language is communication, then, any technology which links together computer, so that learners can "talk" to each other must be worth investigating. The great thing about internet, as it has developed over the past few years, is that not only does it allow communication; it also provides a vast resources - a global CD-ROM, as it were, for teachers hunting for authentic and up-to-date material, or for students engaged in a project or research work.

\section{The Three Broad Areas in which Net Offers} Communicative Activities

1. Communicating with individuals

2. Communicating with groups

3. Live communication

\section{Communicating with individuals:}

Individuals can communicate with each other through NET. Communicating through e-mail "keypads" which is an up-to-date version pen-pals can be made without delays of conventional mail services

\section{Communicating with groups:}

Under this, two services are available. The first is e-mail discussion or LISTSERUS. These services receive contributions from subscribers and automatically mail them out to everyone or the discussion list. 


\section{Live Communication:}

It is also possible to hold "real-time conversations" by logging into one of the multi-user systems. Once connected, any message typed on your screen is seen by all other participants, who can then reply. Typically, these Moos" are configured as schools or universities, with classrooms, lecture theatres, staff rooms, coffee bars etc which can be explored at will.

\section{Types of Information Technology}

1. Electronic mail

2. Electronic lists

3. Electronic journals

4. Streaming audio and video

5. Search engines

6. Remote access to libraries and databases

7. Chat, audio and video conferencing, messaging

8. Web course management

\section{Recommendations}

In order to encourage the use of Information Technology in the teaching and learning of English Language in a Second Language (L2) environment, the following recommendations are made:

1. English Language teachers should be encouraged to learn the use of Information Communication Technology (ICT) in language teaching.

2. School administrators should be encouraged to purchase computer and other Information Communication Technology equipment for the teaching and learning of English in Ogun State Secondary Schools. 
3. Parents should also be encouraged to be computer literate in order to assist their children and wards at home.

Finally, all the secondary school teachers and students should have access to the use of Information Communication Technology gadgets in their schools and use them regularly.

\section{Conclusion}

Ultimately, it is incumbent upon the English Language teacher to integrate the Information Communication Technology (ICT) tools into the secondary schools curriculum in a pedagogically sound and meaningful way. Clearly, target language communication and cultures are easily accessible through current and emerging technologies and information about using these resources is readily available online. The trendy, intrepid and creative teacher would venture into this virtual realm, find authentic resources, and use them to make school language classroom a marvelous place to learn.

\section{References}

Aborisade, P.A. (1977). "The Role of Needs Analysis in Course Design for the EAP Classroom: A Case Study". English Language Teaching Today Vol. 1/1, $19-36$.

Akinbode, J.O. (2006). "Repositioning English Language Education in Nigeria". International Journal of Research in Education, Development Universal Consortia Vol. 3 No.1, June pp. 10-15.

Alimi, M.M. et al (1997). "Team Teaching and Teacher Development". English Language Teaching Today, Vol. $1 / 1 ; 60-64$.

Cook, S. (1990). "Computers and Rumours of Revolution". The Journal of Computing and Society. 1, 29-40. 
Einsenstein, E. (1979). The Printing Press as an Agent of Change. Cambridge, UK; Cambridge University Press pp. $20-28$.

Gergel,T. and Masbit,E.I.(1986)."Psychological and Pedagogical Problems of Effective Computer use in Education Process", Society Education, Vol. XXVIII, Nos 10-11, New York M.E. Sharpe Incorporation pp. $218-219$.

Glister, P. (1997). "Digital Literacy", New York. Wiley Computer Publishing pp. 5-16.

Herwisher, G. (1991). "Research and Recommendations for Computers and Composition Studies". Urban National Council of Teachers of English and Computers and Composition. Pp. 1-4.

Kuang-wu, L. (2000). "English Teachers' Barriers to the use of Computer-Assisted Language Learning". The Internet TESL Journal, Vol. VI, No. 12, December (Retrieved June 26, 2005) http:/iteslj.org/

Lawton, P.J. (1975). "Computer Assisted Learning in Technology" Ville Great Britain. The Pitman Both pp. 181-186.

Murray, D.E. (2000). "Changing Technologies, Changing Literacy Communities". Language Learning and Technology. Vol. 4, No. 2, September, $43-58$.

Odejide, A. (2003). EAP in Nigerian universities of Technology: What Methodologies? Keynote paper at the $1^{\text {st }}$ English Language Teachers Today Conference, 2002. ELTT Journal Vol. 2, No. 1, June 1-6.

Rodgers, T. (2000). Methodology in the New Millennium Forum. Vol. 36, No. 2, April 1-14.

Tyner, K. (1998). "Literacy in a digital world: Teaching and Learning in the Age of Information". Mahwah, N.J. Lawrence Greenbaum Associates. Pp. 5-25. 